\title{
Impact amid absence: The Synod of Dordt and the French Huguenots
}

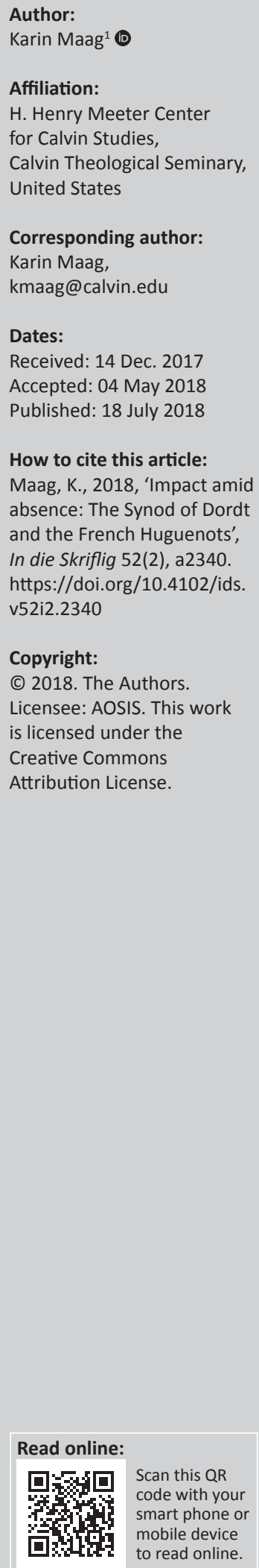

This contribution investigates the reasons behind the absence of delegates from the French Reformed (Huguenot) churches at the Synod of Dordt, setting the reasons for their absence in the broader political and religious context of the times. I argue that the connections between the French Reformed church and the Synod of Dordt were significant both before and after the synod met, but that the Huguenots had a rather different project in mind (religious reconciliation among Reformed Protestants and even possibly between Reformed and Lutheran Christians) when they considered the possibility of an international gathering of Reformed theologians. Although the Huguenot delegates were not present at Dordt and therefore could not directly affect the course of the synod's meeting, their alternate vision for the meeting still persisted even via correspondence during the gathering. At the same time, the synod itself had an impact on the Huguenot church, given that the Canons of Dordt were ratified by the French national synods already by 1620 .

\section{Introduction}

On 13 November 1618 the delegates at the Reformed Synod of Dordt gathered for their opening session 'in the name and in the fear of the Lord' (Sinnema, Moser \& Selderhuis 2015:3). The Acta of the synod begin with the roll call of delegates, listed province by province and country by country. All told, 87 delegates (91 if one includes delegates replacing those who fell ill or died) from the Netherlands and leading Reformed countries came together for what has been described as 'the most significant church assembly in the Reformed tradition' (Sinnema 2017). Twenty-six delegates (28 counting the replacement delegates) from England, Scotland, Geneva, the Swiss cantons and several German territorial states joined their Dutch colleagues at the meeting, highlighting Reformed church leaders' desire to work together to ensure unity of doctrine, worship and polity across Reformed Europe. In fact the Dutch States-General who issued the invitations had to widen the circle of participants from outside the Netherlands when they realised that some foreign Reformed churches had not originally been invited to send representatives and were quite upset at being left out (Sinnema et al. 2015:LXXXVII). Yet, both the roll call and the written list of delegates reveal a gaping absence - no one from the French Reformed church was in attendance. The minutes from the Acta's opening session note: 'No one appeared from the French churches, in spite of having sent dated letters to the king to that effect' (Sinnema et al. 2015:6). So where were they? Surely the Huguenot church leadership wanted to be part of this major international Reformed church conference? Why had they not sent any representatives? It should be noted that the Huguenot delegates were not the only absentees: the delegates from the German principality of Brandenburg had also failed to appear. Indeed their ruler, the margrave Georg-Wilhelm, decided not to have them attend so as not to upset his majority Lutheran subjects (Fornerod et al. 2012). However, the lack of delegates from the large and influential Huguenot church was a more significant loss, as highlighted by the synod's decision to leave the missing French representatives' chairs in place but vacant - a visible token of their absence (Sinnema 2014:109).

This contribution investigates in detail why the French Reformed delegates failed to appear, highlighting their great desire to attend, but also the internal and external political realities that made it impossible for them to come to Dordt. Other scholars such as Patterson (1996) and Sinnema (2014) have carefully investigated the interactions between the Huguenots and the Synod of Dordt, focusing particularly on the role of the leading French theologian and churchman Pierre du Moulin's growing irenicism (Patterson) and his debates with Arminians (Sinnema). Taking a broader perspective, this article sets the French delegates' absence from Dordt in the wider context of Reformed Protestant hopes and expectations for an international Reformed gathering, examining both the roots of the Huguenot aims for such a gathering, and their eventual 
reception of the Synod of Dordt's decisions. In the end, the French Reformed church had to adjust its dreams of a panProtestant alliance - both in the light of the Huguenots' precarious status in the eyes of the French king and as a result of the Synod of Dordt's move to narrow rather than expand confessional boundaries. Although the Huguenot delegates were absent from the Synod of Dordt, the Huguenot church was not cut off from its sister churches - in the end this article argues that the physical absence of the Huguenot delegates did not keep the Huguenot hopes for religious reconciliation from surfacing at Dordt, nor prevent the Synod of Dordt from having an impact on the French Reformed church.

\section{Huguenot hopes for an international synod}

Huguenot hopes for an international gathering of Reformed theologians predate the Synod of Dordt by at least 15 years. Already in 1603, the pastors and elders, meeting at the French national synod of the Reformed church in Gap, wrote a series of letters to their counterparts in Geneva, Basel, Bern, Zurich and the German Reformed churches, asking them to join the French Reformed church in its efforts for greater Reformed unity. In 1603 the plan involved circulating each church's confession of faith to the others so that there could be mutual doctrinal agreement, and so that the Reformed churches of Europe could be more strongly united against the Church of Rome (Campagnolo 1989:261-279). Many of these Huguenot aspirations were centred around the person of King James I, whose accession to the English throne in 1603 seemed to signal a new openness to strengthening international Reformed unity. French historian Jacques Pannier suggested that King James I was, in fact, deeply interested in marshalling Protestants across Europe to work on greater unity as long as these Protestants all agreed on justification by faith as their doctrinal cornerstone (Pannier 1922:436). Enlisting the English king's support was the hope of leading Huguenots, including the French Reformed pastor Pierre du Moulin, pastor at Charenton near Paris, and Philippe DuplessisMornay, a major figure among the Huguenot nobility. Duplessis-Mornay had been in touch with King James I already shortly after the latter's accession, as the French nobleman noted in a letter to the English ambassador in France, Sir Thomas Edmondes, on 4 October 1613:

Monsieur, a little after it had pleased God to call the king your sovereign to this great estate, I proposed that there was no work more worthy of his piety, wisdom, and greatness, than the concord of all the Protestant Churches of Christendom, and for the sake of this I conferred several times, both by writing and in person with Messieurs his ambassadors in this kingdom, [and] even made to them some proposals about means which I believed very expedient in order to succeed. (Patterson 2000:164)

Although the Huguenot hopes for action on King James I's part remained unfulfilled at that early stage, by 1613 the French Reformed leaders had some grounds for their expectation that an international Reformed conference would shortly be convened under the British ruler's patronage. In March 1613 Pierre du Moulin sent King James
I a draft proposal for such a gathering (Sinnema 2014:101). By May 1614 at its triennial gathering, the French national synod of the Huguenot church meeting in Tonneins, received for information a fascinating document laying out what such an international Reformed conference might look like. This proposal, reworked by Du Moulin with the advice of Duplessis-Mornay (Greengrass 2006:423-461; Patterson 2000:171) on the basis of his earlier draft and issued only four years before the Synod of Dordt began its work, offers important insights into one particular vision of what an international gathering of Reformed leaders might accomplish.

The six-page document, headed 'Means proposed to bring together the Christian churches that have shaken off the Pope's yoke, and to diminish the differences that have emerged among these churches or that may emerge in future' already signals by its title that the aim of the putative gathering would be to focus on achieving a united Protestant front (Aymon 1710:57). In that sense, this document offers a very different view than that of the Synod of Dordt whose main concern was to deal with doctrinal divergences within the Reformed faith by firmly reasserting the orthodox position.

Over the course of 21 articles, the Tonneins document lays out a vision for church unity among Reformed Protestants in the first instance, and then in a second phase, among Reformed and Lutheran believers. In the first phase, the document calls for gathering one or two representatives from England, France, the Netherlands, the Swiss Protestant cantons and the German Reformed princes in a place of safety for the conference, recommending the Dutch province of Zeeland as being centrally located and easily accessible for everyone. The memorandum suggests selecting delegates who are 'peaceful, serious, God-fearing, prudent, and not contentious' (Aymon 1710:58), and recommends surrounding the assembly with prayer and fasting, both by the delegates and by the members of the sending churches. In a faint echo of the Synod of Gap's circular letter, the document also advocates finding common ground by literally laying on the table the various confessions of the Reformed churches represented in the gathering, and focusing on the points of common agreement. Finally, the document calls for the delegates to celebrate the Lord at the close of the conference, 'as a sign of their unity', during which the pastors from England and the other nations would take communion together and serve the elements to each other (Aymon 1710:57-65). Presenting the plan as 'a pious, necessary, and very feasible undertaking', Du Moulin recommends avoiding any contentious topics liable to cause divisions such as debates over free will, the perseverance of the saints and predestination, describing these as 'unnecessary to our eternal salvation' (Aymon 1710:57). Thus, this plan for an international Reformed conference was grounded in reaching unity on essentials and leaving aside disputed topics for the greater goal of strengthening ties between the Reformed churches. 
In its second section, the document moved to planning for a subsequent gathering between Reformed and Lutheran theologians. Here too, the aim was to find common theological ground and avoid debated matters as far as possible. The document did, however, acknowledge the continued significant differences in the respective confessions' understanding of the Lord's Supper. The best that could be hoped for, according to the document's author (who was very hopeful indeed), was for the Lutherans to put aside their insistence on ubiquity for the sake of peace (Aymon 1710:61). Here too, the author dreamed of a joint Lord's Supper celebration in which Lutheran and Reformed pastors would share the sacrament with each other (Aymon 1710:61).

Scholars commenting on this text (Patterson 2000:171-179) have noted the improbability of the plan, especially in its search for a common Reformed-Lutheran front. Even at the time, Du Moulin's English counterparts thought that the Lutheran-Reformed section of the document was unrealistic (Fornerod et al. 2012). But the fact that the document was sent in an earlier draft form to King James I and was recorded in the minutes of the National Synod of Tonneins, provides evidence of a vision for an international Reformed gathering that carried weight. From Tonneins, the project was sent back to the provincial synods for discussion, and by 1617 at the next national synod in Vitré, delegates established a commission to look into the possibilities of holding such a gathering. The commission members included Pierre du Moulin, two fellow pastors, Jean Chauve and André Rivet, and Daniel Chamier, a professor of theology at the Academy of Montauban (Patterson 1996:243-244; Sinnema 2014:107).

\section{The Huguenots and the Synod of Dordt}

By 1618, however, the international situation had changed. The Dutch government took the lead in calling together an international Reformed conference. Those selected to attend the Synod of Dordt on behalf of the French Reformed church, namely Du Moulin, Chauve, Rivet and Chamier were precisely those most closely involved in the earlier reunification plans. Already from the start of the invitation process, however, it was clear that the path to getting the Huguenot delegates to Dordt was not straightforward. Between June and October 1618, the Dutch ambassador in Paris, Gideon van Boetzelaar, met with King Louis XIII or his representatives on five separate occasions to urge royal approval of the delegates and permission for their journey to Dordt. Although at first the ambassador seemed hopeful that royal authorisation would be granted, by early October he was reduced to trying to convince the king to approve all four delegates and not just two (Du Moulin and Rivet). By 20 October van Boetzelaar had to write to the States-General to tell them that the king had, in fact prohibited all four men from leaving France to attend the Synod of Dordt (Sinnema et al. 2015:LXXIX-LXXX).

The reasons why King Louis XIII refused permission for the Huguenot delegates to attend the synod have been extensively debated. Pannier argued that King Louis XIII objected in principle to allowing French subjects to attend an international religious gathering outside France and noted Henri II's similar unwillingness to send French Catholic representatives to the Council of Trent (Pannier 1922:444445). Sinnema points to the start of the Bohemian Protestants' uprising earlier in 1618 and King Louis XIII's concerns about the Huguenots meeting up with other Protestants and potentially spreading unrest in France upon their return (Sinnema 2014:108). Apart from these broader concerns, however, a more immediate reason for the king's refusal to allow the Huguenot delegates was due to political rather than religious factors. The former representative of the StatesGeneral to the French royal court, François d'Aerssen, had left France under a cloud in 1613 - accused of spying, greed and insolence. On his return to the Netherlands, d'Aerssen had become involved in the political turmoil, siding with Maurice of Nassau against Johan van Oldenbarnevelt, the State of Holland's advocate or chief statesman. D'Aerssen even suggested that Oldenbarnevelt had supported putting the Dutch provinces under French control. King Louis XIII meanwhile considered Oldenbarnevelt an ally and strongly objected to d'Aerssen's verbal and written insinuations. Because the States-General refused to take strong action against d'Aerssen, King Louis XIII decided to retaliate by preventing the French Huguenot delegates from travelling to Dordt. According to van Boetzelaar:

[the king] has decided not to let any French pastor attend the synod, because he is getting so little satisfaction regarding this issue [the d'Aerssen slander], even though earlier on he had been willing to grant permission to Du Moulin and Rivet, two of the four chosen by the French churches. (Fornerod et al. 2012; Académie royale de Belgique 1866:106-121)

Because of this long-drawn-out process of trying to obtain the king's permission, the four delegates were left unsure for months as to whether their trip would be allowed or not. While Rivet and Du Moulin remained in Paris, Chamier and Chauve made it as far as Geneva by early November 1618 . While in Geneva, Jean Chauve conferred with the Genevan Company of Pastors, asking their advice about whether or not he and Chamier should head on to Dordt (Fornerod et al. 2012). Among the reasons the Company of Pastors gave to support their trip was an endorsement of the Huguenot project of a Europe-wide Reformed summit:

even if they [Chauve and Chamier] were to arrive a bit late [to Dordt], they could still play an important role, not only in terms of the main reason why the synod has been called together, but also to build the foundation and present the plans for their international Reformed gathering. (Fornerod et al. 2012)

In the eyes of the Genevans, at least, the Huguenot hopes for a general meeting of Reformed leaders to find common ground were not dead in the water.

In fact, even though the four Huguenot delegates were unable to attend the Synod of Dordt in person, their influence still penetrated the gathering and their hopes for a wider 
push for religious reconciliation persisted. In December 1618 Pierre du Moulin wrote from Paris to the British ambassador in the Netherlands, Dudley Carleton, to urge him to get the synod delegates at Dordt to move beyond their focus on the Remonstrant threat and make progress on finding common doctrinal ground. As far as the French pastor was concerned, the Synod of Dordt provided the ideal venue to work on the first phase of the proposal for religious reconciliation set out at the French National Synod of Tonneins. In his letter, Du Moulin strongly suggested that the Synod of Dordt should work to come to a common confession of faith which all delegates would sign and bring back to their respective national church bodies for ratification. Du Moulin recommended avoiding matters of church polity and church discipline in the confession, because he feared that the delegates would not come to agreement on these issues. The common confession would then regulate the doctrinal stance of the signatory churches who would be unable to make doctrinal changes without the agreement of all the other churches in the group. Du Moulin still clung to his vision of stronger Reformed doctrinal unity as a first step to be followed by a rapprochement with the German Lutherans. $\mathrm{Du}$ Moulin's plans for closer bonds with the Lutheran churches called for a Lutheran and Reformed meeting to take place within six months, focusing on paths towards agreement and mutual toleration. Once again, as in previous years, Du Moulin called on King James I to lend his weight to these plans, for, as Du Moulin wrote:

I believe these plans are straightforward and doable, especially if the King of Great Britain were to bring his authority to bear and make a proposal to this effect to the synod. (Milton 2005:152-154)

Although Carleton did transmit Du Moulin's letter to King James I, the Dutch leadership was distinctly lukewarm about the French suggestion, and any plans to start by drafting a mutually-acceptable confession for the Reformed churches were quietly dropped by early 1619 (Sinnema 2014:109-113). It is possible, as suggested by Sinnema $(2014: 109-115,136)$ and Patterson (2000:269-271), that if Du Moilin and his fellow Huguenot delegates had been physically present at Dordt, the impetus for finding common confessional ground would have gained more traction.

\section{The reception of the synod's work in France}

Yet, the unfolding of proceedings at the Synod of Dordt (with no French delegates present) and the story of the reception of the synod's decisions in France from 1619 onwards suggests that matters were moving in a very different direction. By 1620 at the National Synod of Alais, the overall tenor of the Huguenot church's relations with its sister Reformed churches had shifted to a more anxious tone. By 1620, instead of crafting plans to bring Protestant believers of various stripes around the table to establish commonalities, the Huguenots were worrying about the potential penetration of Arminianism in France. As Pannier (1922:451-457) pointed out, France did prove a reasonably welcoming place of refuge for Arminians forced to leave the Netherlands and the Duchy of Sedan, including Simon Episcopius, Johannes Wtenbogaert, Hugo Grotius, and Daniel Tilenus. The minutes of the national synod note:

we should be thinking about ways to prevent the Arminians, who have disturbed the Low Countries, from slipping into this kingdom. Having accepted this recommendation as praiseworthy, valid and necessary for the peace of the church and the maintenance of pure doctrine, and to consolidate our union to a greater extent with all other Reformed Churches [...] we must work to avoid this evil by the same means as they [the Dutch] have used to eradicate it. (Aymon 1710:182)

The minutes went on to state that the full text of the Canons of Dordt had been read out to the assembly and that, after examining the articles, the delegates 'received and approved them unanimously, as conforming very much to the Word of God and to the Confession of Faith of our churches' (Aymon 1710:182). In order to ensure that the Canons of Dordt would be upheld by the French Reformed church, the pastors and elders at the National Synod of Alais agreed that everyone present at the synod was to swear in turn that 'they agreed with this doctrine, and that they will defend it with all their power until their last breath' (Aymon 1710:183). The canons and the attached oath were then to be sent to each provincial synod and to each of the Huguenot academies. All currently serving pastors, elders, professors and teachers also were to swear to this oath as well as anyone subsequently seeking ordination or a post as professor in one of the aforementioned academies (Aymon 1710:183).

And yet, in the midst of the pressure to define exactly what was and what was not orthodox Reformed doctrine on predestination, and to set up doctrinal markers to establish which beliefs were acceptable and which were beyond the pale, the French Reformed hopes for a path of reconciliation still surfaced, albeit less openly than in the past. The same section of the minutes from Alais laying out the importance of the canons, the accompanying oath and the penalties for non-compliance ended with sentences that echoed the Huguenots' earlier aspirations. The synod exhorted that:

all those charged with the care of souls to walk at the same pace, avoiding vain and esoteric questions, not delving into God's secret counsel beyond the boundaries of his Word. They should ignore hidden things and not engage in illicit topics. They should ensure that the complete doctrine of predestination contributes to the practice of virtues, the comfort of souls, the peace of consciences, and the study of piety, so that any grounds of opposition disappears and that we can remain united in one faith with our brothers in the Netherlands and with the other churches outside this kingdom. (Aymon 1710:183)

Thus, although the Huguenot church in 1620 did implement the observance of the Canons of Dordt, it did so within a framework that stressed a pastoral approach geared towards unity, rather than via a rigid search for doctrinal dissidents. The Huguenot church did begin to put the canons into practice. For instance, the list of deposed pastors in the 
minutes of the 1623 synod included Jean Balset, a former pastor in the Dauphiné, removed from ministry by his provincial synod for Arminianism (Aymon 1710:295-296). Pastors outwardly holding Arminian views could no longer remain in office. However, even as late as 1623, the Huguenot church proceeded cautiously in its approach to those who simply held Arminian views without trying to spread them. Following a query from the province of Ile de France, the National Synod of Charenton decided that pastors were to try to win over those privately holding Arminian views, but if these proponents of Arminianism refused to change their outlook after three months, they were then to be barred from the Lord's Supper. Meanwhile, those publicly espousing Arminian views were to face church discipline (Aymon 1710:278; Sinnema 2014:126-127).

Yet, pastors who either refused to take the 1620 oath or who adopted Arminianism, but then changed their minds, could find that their fellow pastors and elders at the national synod were willing to reintegrate them, as was the case for Etienne de Courcelles. De Courcelles had first been a pastor in Fontainebleau near Paris, and then at Amiens, and refused to sign his agreement to the Canons of Dordt when required to do so at the meeting of the Provincial Synod of Charenton in 1622. He was then dismissed from his pastoral charge. In 1623 at the national synod held also at Charenton, De Courcelles apologised and said that he now rejected Arminian views and was willing to subscribe wholeheartedly to 'the doctrine received by the Reformed churches of this kingdom' (Aymon 1710:280). After examining him and hearing his stated desire to affirm all the doctrines and canons laid out at the Synod of Alais, the delegates readmitted De Courcelles to the pastoral office and organised some temporary funding for him until he could find a church (Aymon 1710:281; Sinnema 2014:124). In this instance, De Courcelles' willingness to abide by the doctrinal standards of Dordt proved short-lived, given that he sought refuge among Dutch Arminians in the Netherlands within a few years and ended up teaching theology in the Arminian seminary in Amsterdam by the mid-1630s. However, the willingness of the National Synod of Charenton to accept De Courcelles back among its ranks, even though he had previously publicly opposed its policies regarding adopting the Canons of Dordt, is a noteworthy sign that divisions between proponents and opponents of the Synod of Dordt's decisions were not hard and fast.

Yet, even this careful attempt to both adopt the Canons of Dordt and still stress the importance of minimising doctrinal controversies to foster religious unity among the Reformed within and outside France, ran into trouble. The main problem was King Louis XIII's continued suspicion about Huguenot involvement in anything outside France. Not only had the king been unwilling in the end to allow the French delegates to leave France to go to Dordt, he also proved equally unwilling to have any outcomes from the Synod of Dordt to come back into France. In 1623 the National Synod of Charenton received a lengthy report from delegates who had recently returned from the French royal court. The delegates reported that, although the king's advisors received them warmly and assured them of the king's continued desire to support his Reformed subjects, King Louis XIII was perturbed about two specific issues. The two matters were in fact linked, because both involved what the king perceived as external threats or interference in his realm. The first problem was the presence of foreign Reformed pastors in France. The king's spokesmen laid out the second issue in the following terms:

The second point has to do with the synod of Alais. While his majesty has no intention of taking away our churches' freedom in matters of faith, nor of making any changes in our religion, our doctrine, or our discipline, his majesty is not at all happy that the national synod of the Reformed church held at Alais forced pastors to take an oath to uphold a doctrine that was defined in the territory of a foreign government. While his majesty does protect the Reformed faith, there should be no misunderstanding. The king has no intention of protecting a new and foreign faith. (Aymon 1710:261)

It is interesting to realise that the king and his advisors were reading the Huguenot national synod minutes so closely as to take note of the oath to uphold the Canons of Dordt. In response to the king's opposition to this oath, the Huguenot delegates at court bent over backwards to provide reassurance. They acknowledged that the Synod of Dordt had addressed doctrinal issues that caused trouble in the Low Countries, but argued that the decisions of the Dutch synod meshed fully with the Huguenot confession of faith. In other words, the Canons of Dordt were not ushering in any new beliefs and there was no intention to make the king into the protector of any new or foreign doctrine. In reply, the king reiterated his unwillingness to intervene in Reformed doctrinal debates, but stated that 'no one should base his faith on the faith of another, or swear to a foreign faith, but that everyone should be free to believe whatever they want' (Aymon 1710:262).

In the light of the king's displeasure about the Huguenot swearing oaths to uphold foreign doctrine, the National Synod of Charenton decided that discretion was the better part of valour, and altered the wording of the oath that pastors, elders and educators were to take to uphold the Canons of Dordt, to downplay the canons' geographical origin and highlight instead the doctrinal conformity of the canons with the Huguenots' foundational documents (Aymon 1710:262; Sinnema 2014:126).

\section{Conclusion}

This account of the French Huguenots and the Synod of Dordt highlights some important issues. Firstly, although the four French delegates never made it to the meeting, the decisions taken at Dordt had a clear impact in the French Reformed church. Indeed, the French Reformed church was the only body outside the Netherlands to officially accept the Canons of Dordt. Even though the implementation of the canons was challenging, given both royal opposition 
and the penetration of Arminian views in the Huguenot church, the French willingness to make the Canons of Dordt part of their confessional package is a striking sign of the Synod of Dordt's impact on the Huguenots at the time.

Secondly, even though the French delegates were absent from the meetings in Dordt, they did not give up on their vision of a broader Reformed and pan-Protestant confessional unity. In their writings, their correspondence and their work at the national and international level, the Huguenots offered a broader view of the need for wider Protestant cooperation in the face of an increasingly confident Roman Catholic Church. Although Du Moulin's proposals never reached the floor of the Synod of Dordt, these were part of a movement whose effects can be seen yet today in current ecumenical encounters and agreements.

Thus, in spite of their absence from the Synod of Dordt, the Huguenots were neither locked off from international Reformed influence, nor were their voices silenced. King Louis XIII's unwillingness to have the Huguenot delegates attend the Synod of Dordt could neither prevent the national Huguenot church from subscribing to the outcomes of that synod, nor could he keep them from making their voices heard, albeit in writing rather than in person. The chairs for the French delegates at Dordt in 1618-1619 were indeed empty, but their bonds with the international Reformed community and its core issues, as highlighted at Dordt, remained unbroken.

\section{Acknowledgements Competing interests}

The author declares that she have no financial or personal relationships which may have inappropriately influenced her in writing this article.

\section{References}

Académie royale de Belgique, 1866, Biographie nationale de Belgique, vol. 1, Thiry-Van Bruggenhoudt, Brussels.

Aymon, J. (ed.), 1710, Tous les synodes nationaux des églises réformées de France, vol. 2, C. Delo, The Hague.

Campagnolo, M., 1989, 'Deux lettres du synode national de Gap aux églises soeurs', Bulletin de la Société de l'histoire du Protestantisme Français 135, 261-279.

Fornerod, N., Boros, P., Dubois, T. \& Labarthe, O. (eds.), 2012, Registres de la compagnie des pasteurs de Genève, vol. 14, Droz, Geneva.

Greengrass, M., 2006, 'Philippe Duplessis-Mornay, Jacques VI et ler, et la réunion du christianisme, 1603-1619', Albineana, Cahiers d'Aubigné 18(1), 423-461. https:// doi.org/10.3406/albin.2006.1072

Milton, A. (ed.), 2005, The British Delegation and the Synod of Dort (1618-1619), Boydell Press, Woodbridge, VA.

Pannier, J., 1922, L'Eglise réformée de Paris sous Louis XIII (1610-1621), Honoré Champion, Paris.

Patterson, W.B., 1996, 'Pierre Du Moulin's Quest for Protestant Unity, 1613-18', in R. Swanson (ed.), Unity and diversity in the Church, pp. 235-250, Blackwell, Oxford.

Patterson, W.B., 2000, King James VI and the reunion of Christendom, Cambridge University Press, Cambridge.

Sinnema, D., 2014, 'The French Reformed Churches, Arminianism, and the Synod of Dort (1618-19)', in M. Klauber (ed.), The theology of the French Reformed Churches: From Henri IV to the Revocation of the Edict of Nantes, pp. 98-135, Reformation Heritage Books, Grand Rapids, MI.

Sinnema, D., 2017, 'Remembering the Synod of Dordt', Christian Courier, 06 March 2017, viewed 11 October 2017, from http://www.christiancourier.ca/columns-oped/entry/remembering-the-synod-of-dordt

Sinnema, D., Moser, C. \& Selderhuis, H. (eds.), 2015, Acta of the Synod of Dordt, Vandenhoeck \& Ruprecht, Göttingen. 